\title{
A Comparative Study for Adsorptive Removal of Remazol Red R and Remazol Black B from Aqueous Solution by ZnO
}

\author{
A Z M Mainul Islam Mazumder ${ }^{1}$, Chowdhury Raihan Bikash ${ }^{1}$, Md. Ataur Rahman ${ }^{2}$ and Md. Mufazzal \\ Hossain $^{* 1}$ \\ ${ }^{1}$ Department of Chemistry, Dhaka University, Dhaka-1000, Bangladesh \\ ${ }^{2}$ Department of Chemistry, Jagannath University, Dhaka-1100, Bangladesh
}

(Received: 2 April 2018 ; Accepted: 2 July 2018 )

\begin{abstract}
Adsorptive removal of remazol red R (RRR) and remazol black B (RBB) from aqueous solution has been investigated by using $\mathrm{ZnO}$ as an adsorbent. Time for adsorption equilibrium, kinetics of adsorption at different initial concentrations of dyes and adsorption isotherms at different temperatures have been studied. Adsorption capacity increased with increasing initial dye concentration. The pseudo first-order and pseudo second-order kinetics were used to describe kinetic data and the rate constants were evaluated. Experimental data fits better in the pseudo second-order kinetic model than in the pseudo firstorder kinetic model for both the dyes. Langmuir and Freundlich isotherm models were applied to describe the adsorption of $\mathrm{RRR}$ and $\mathrm{RBB}$ onto $\mathrm{ZnO}$ powders. Langmuir isotherm model provided a better correlation for the experimental data in comparison to the Freundlich isotherm model. Adsorption of both RRR and RBB on $\mathrm{ZnO}$ are physical in nature and increases with decreasing temperature. The equilibrium adsorption capacity decreases from $3.43 \mathrm{mg} / \mathrm{g}$ at $20{ }^{\circ} \mathrm{C}$ to $2.36 \mathrm{mg} / \mathrm{g}$ at $40{ }^{\circ} \mathrm{C}$ for RRR whereas that in the case of RBB changes from $0.77 \mathrm{mg} / \mathrm{g}$ at $30{ }^{\circ} \mathrm{C}$ to $0.75 \mathrm{mg} / \mathrm{g}$ at $40{ }^{\circ} \mathrm{C}$. Adsorption of $\mathrm{RRR}$ on $\mathrm{ZnO}$ was found to be three times higher than the adsorption of $\mathrm{RBB}$ at a particular temperature. A model for adsorption of both the dyes has been proposed.
\end{abstract}

Keywords: Adsorption, remazol red R, remazol black B, kinetics of adsorption, isotherms.

\section{Introduction}

Textile, leather, pulp and paper, food and plastics industries have been using dyes extensively. These dyes are classified as acid and reactive dyes, cationic and anionic dyes etc ${ }^{1-3}$. Among different types of dyes reactive dyes are most commonly used. Reactive dyes differ from all other classes of dyes in the way that they form covalent bond to the textile fibers. Characteristic bright color, simple method of application and low consumption of energy are the main reasons for extensive use of reactive dyes in the textile industries $^{4,5}$. For several organisms reactive dyes are very toxic. Once released to the aquasphere reactive dyes possess a great threat to aquatic life. They block out the sunlight, hence reduce photosynthesis which cause the decrease in concentration of dissolved oxygen ${ }^{6,7}$. Moreover, dyes have carcinogenic and mutagenic effects on human and other life forms ${ }^{8,9}$. Azo compounds remazol red $\mathrm{R}$ (RRR) and remazol black B (RBB) (Fig. 1) both are reactive dyes and are frequently used in textile industries. Hence textile industry effluents contain these toxic reactive dyes until properly treated.

There are various techniques for removing reactive dyes from aqueous solution. Among them reverse osmosis, chemical coagulation, trickling filter, activated sludge and photodegradation techniques have been investigated extensively ${ }^{10-13}$. Adsorption is another effective method for dye removal from aqueous solution. During adsorption, dye molecules dissolved in aqueous solution get attached to the surface of the adsorbents ${ }^{14,15}$. The possibility of using chitin $^{16,17}$, activated carbon ${ }^{18,19}$, silica ${ }^{12}$, peat ${ }^{20,21}$ and others $^{22-28}$ as adsorbent has already been studied. Zinc oxide powders have been used as semi-conductors, photocatalyst, non-linear optical materials etc. Zinc oxide powders can also act as an effective adsorbent ${ }^{29,30}$. In this work, zinc oxide was employed as an adsorbent for removal of RRR and RBB from aqueous solution. The dyes were chosen because one of the dye (RRR) has one longer chain with anionic $\left(-\mathrm{OSO}_{3}^{-}\right)$group, whereas the other, $\mathrm{RBB}$ has two such chains. Adsorption capacity, kinetic and isothermal parameters were evaluated and compared.

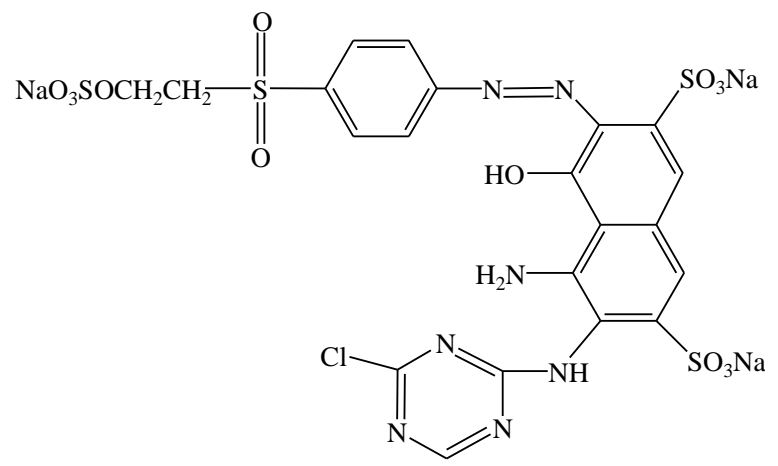

Fig.1. (a) Remazol red R (RRR)

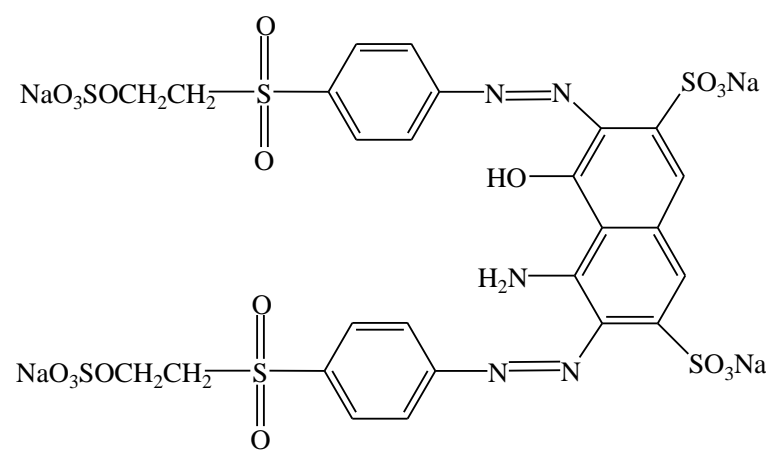

Fig. 1. (b) Remazol black B (RBB) 


\section{Experimental}

\section{Materials and techniques}

The adsorbent $\mathrm{ZnO}$ was obtained from Merck, Germany and was used as purchased. Commercial grade RRR and RBB dyes were purchased from Dyestar, Germany and was used without further purification. UV-visible spectra of both RRR and RBB were recorded on a Shimadzu UV1650 spectrophotometer. SWB-20, HAAKE thermostatic shaker was used for shaking at $200 \mathrm{rpm}$ and a laboratory centrifuged machine (Digisystem, DSC-N158A) was used to centrifuge $(3000 \mathrm{rpm})$ the dye solution after adsorption.

\section{Adsorption proces}

The wavelengths of maximum absorbance, $\lambda_{\max }$ were determined from the absorption spectra and $\lambda_{\max }$ were found 516 and $594 \mathrm{~nm}$ for RRR and RBB respectively.

In order to estimate equilibrium time of adsorption of RRR and RBB, experiments were performed in well stopper reagent bottles containing $30.0 \mathrm{~mL}$ of the dye solutions. A fixed amount of $\mathrm{ZnO}$ was added to the dye solution. The reagent bottles were shaken in a thermostatic shaker at 30 ${ }^{\circ} \mathrm{C}$. The reagent bottles were successively withdrawn after a definite time interval and $10.0 \mathrm{~mL}$ of supernatant liquid from each bottle was centrifuged and the UV-visible spectra were recorded to determine the change in concentration of the dye solutions.

For kinetic data a series of reagent bottles with dye solutions and fixed amount of $\mathrm{ZnO}$ were stirred at $30{ }^{\circ} \mathrm{C}$ and the changes in concentration were monitored after 5, 15, 30, 45, 60, 75 and $90 \mathrm{~min}$ during the adsorption process. The adsorption isotherm for each dye was studied through the batch method in which concentrations varied from $1.0 \times 10^{-5}$ $\mathrm{mol} \mathrm{L} \mathrm{L}^{-1}$ to $1.0 \times 10^{-4} \mathrm{~mol} \mathrm{~L}^{-1}$ for RRR and $1 \times 10^{-5} \mathrm{~mol} \mathrm{~L}^{-1}$ to $5 \times 10^{-5} \mathrm{~mol} \mathrm{~L}^{-1}$ for RBB. Adsorption isotherm was studied at three different temperatures, $20^{\circ} \mathrm{C}, 30^{\circ} \mathrm{C}$ and $40{ }^{\circ} \mathrm{C}$.

The amount adsorbed was determined from difference between the initial concentration $\left(\mathrm{C}_{\mathrm{o}}\right)$ in aqueous solution and the concentration of unadsorbed dye that found after centrifugation. Adsorption isotherm was obtained by plotting $\mathrm{q}_{t} \mathrm{vs}_{\mathrm{e}}$, where $\mathrm{q}_{\mathrm{t}}$ is the amount of adsorbed (in $\mathrm{mg}$ ) per gram of adsorbent, $\mathrm{ZnO}$ at time $\mathrm{t}, \mathrm{C}_{\mathrm{e}}$ is the equilibrium concentration of dye. The value of qt was obtained using the following relation.

$$
q_{t}=\frac{\left(C_{0}-C_{e}\right) V M}{Z} \times 1000
$$

Where, $\mathrm{V}=$ Volume (L) of the solution in each bottle

$\mathrm{M}=$ Molecular weight of the dye $\left(\mathrm{g} \mathrm{mol}^{-1}\right)$

$\mathrm{Z}=$ Amount of $\mathrm{ZnO}(\mathrm{g})$

\section{Results and Discussion}

\section{Estimation of equilibrium time}

In the process of adsorption, dye molecules diffused through the boundary layer into the porous structure of the adsorbent. Adsorption of RRR and $\mathrm{RBB}$ on $\mathrm{ZnO}$ at $30{ }^{\circ} \mathrm{C}$ were studied by varying the initial concentration of dyes. Higher initial concentration of dyes results in higher adsorption capacity of the adsorbent ${ }^{29}$. Maximum 3.29 $\mathrm{mg} / \mathrm{g}$ of RRR was adsorbed for $10 \times 10^{-5} \mathrm{~mol} \mathrm{~L}^{-1}$ of RRR while $0.77 \mathrm{mg} / \mathrm{g}$ was the maximum adsorption capacity for $5 \times 10^{-5} \mathrm{~mol} \mathrm{~L}^{-1}$ of RBB. For all the experiments, dye concentrations were decreased with time and after a certain time, the concentration of dye became steady. At this point rate of adsorption become equal to the rate of desorption of dye molecules. Time required to reach this equilibrium condition was same irrespective of the initial concentration of the dye solution. Approximately 60 minutes and 70 minutes were required to reach the equilibrium for the adsorption of RRR (Fig.2) and RBB (Fig.3), respectively. These results prove that $\mathrm{ZnO}$ is an effective adsorbent because bioadsorbents take much longer time to reach adsorption equilibrium $^{26,28}$.

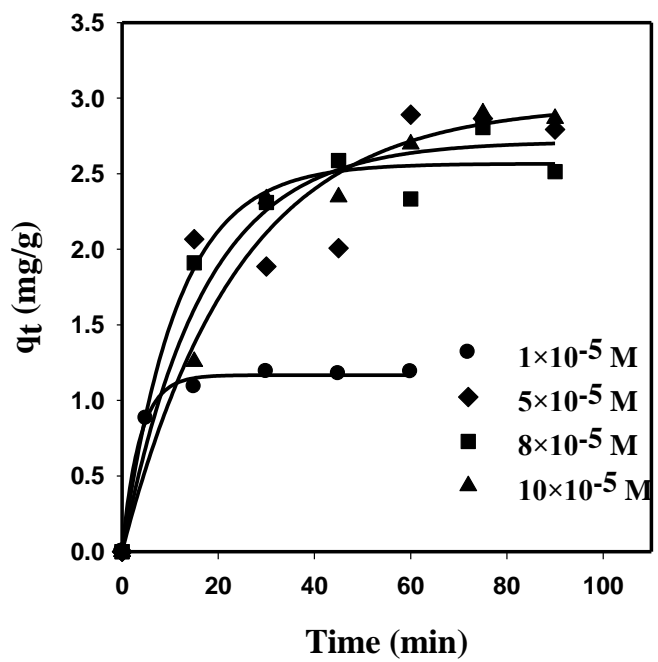

Fig. 2. Estimation of equilibrium time for adsorption of different initial concentrations of RRR on $0.2 \mathrm{~g} / 30.0 \mathrm{~mL} \mathrm{ZnO}$ at $\mathrm{pH} 5.83$.

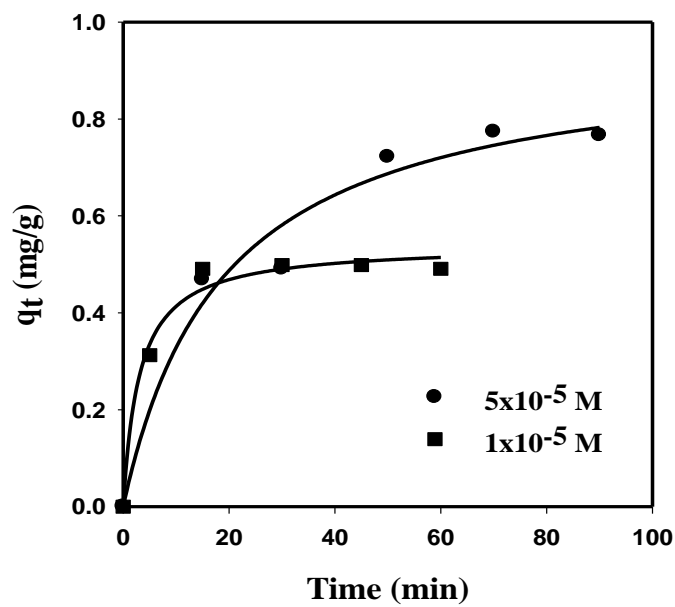

Fig. 3. Estimation of equilibrium time for adsorption of different initial concentrations of $\mathrm{RBB}$ on $0.4 \mathrm{~g} / 30.0 \mathrm{~mL} \mathrm{ZnO}$ at $\mathrm{pH} 5.83$. 


\section{Kinetics of adsorption of RRR and $\mathrm{RBB}$ on $\mathrm{ZnO}$}

There are numerous kinetic models proposed to elucidate the mechanism of dye adsorption. In this work two different kinetic models, Lagergren pseudo-first order and Ritchie pseudo-second order kinetic models, were used.

Lagergren pseudo-first order model ${ }^{31,32}$ is expressed as follows:

$$
\log \left(\mathrm{q}_{\mathrm{e}}-\mathrm{q}_{\mathrm{t}}\right)=\log \mathrm{q}_{\mathrm{e}}-\mathrm{k}_{1} \mathrm{t}
$$

According to the pseudo-second order model ${ }^{33}$, the dye adsorption kinetics can be described as

$$
\frac{t}{q_{t}}=\frac{1}{k_{2} q_{e}^{2}}+\frac{1}{q_{e}}
$$

Where, $\mathrm{q}_{\mathrm{t}}$ is the amount of dye adsorbed $(\mathrm{mg} / \mathrm{g})$ at times $\mathrm{t}$, $\mathrm{q}_{\mathrm{e}}$ is the maximum adsorption capacity $(\mathrm{mg} / \mathrm{g}$ ) for both pseudo-first order and pseudo-second order adsorption, $\mathrm{k}_{1}$ and $\mathrm{k}_{2}$ are the pseudo-first order $\left(\mathrm{min}^{-1}\right)$ and pseudo-second order $\left(\mathrm{g} \mathrm{mg}^{-1} \mathrm{~min}^{-1}\right)$ rate constants, respectively. The values of pseudo-first order and pseudo-second order rate constants for adsorption of RRR (Fig. 4a and Fig. 4b) and RBB (Fig. 5a and Fig. 5b) are calculated and recorded in Table. 1. The correlation coefficients $\left(R_{2}^{2}\right.$ for pseudo-first order model and $R_{2}^{2}$ for pseudo-second order model) show that pseudo-second order model fits the experimental data better than the pseudo-first order model for bothRRR and RBB. In other words, adsorption of RRR and RBB on $\mathrm{ZnO}$ follows pseudo-second order kinetic model. Several research groups have found that adsorption of dye molecules on bioadsorbent or $\mathrm{ZnO}$ surface follows pseudosecond order kinetic model ${ }^{27-30}$ and our findings agrees well.

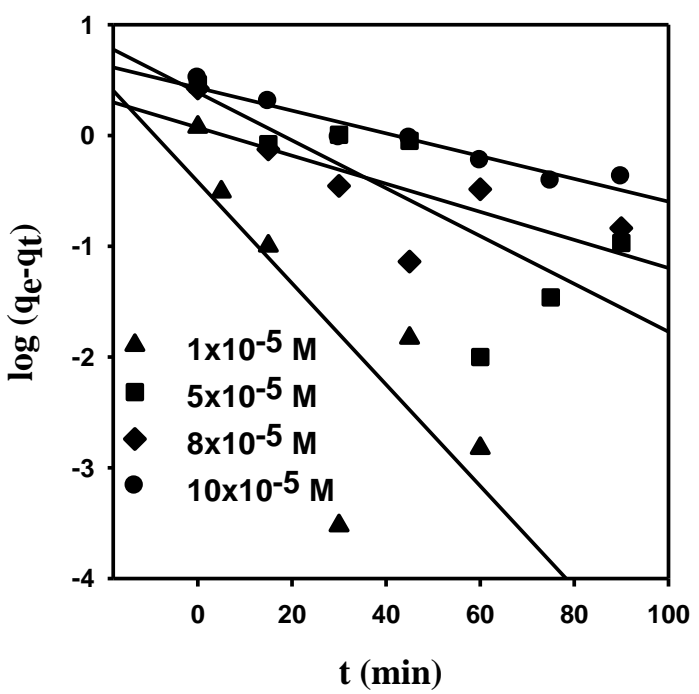

Fig. 4. (a) Pseudo first-order kinetic model for adsorption of RRR on $0.2 \mathrm{~g} / 30 \mathrm{~mL} \mathrm{ZnO}$ at $\mathrm{pH} 5.83$.
Table. 1. Kinetic parameters of pseudo first-order and pseudo second-order model for adsorption of RRR and

\begin{tabular}{|c|c|c|c|c|c|}
\hline \multirow[t]{2}{*}{ Dye } & \multirow{2}{*}{$\begin{array}{l}\mathrm{C}_{0} \times 10^{5} \\
/ \mathrm{mol} \mathrm{L}^{-1}\end{array}$} & \multicolumn{2}{|c|}{$\begin{array}{l}\text { Pseudo-first order } \\
\text { model }\end{array}$} & \multicolumn{2}{|c|}{$\begin{array}{l}\text { Pseudo-second order } \\
\text { model }\end{array}$} \\
\hline & & $\begin{array}{c}\mathbf{k}_{1} \\
/ \mathrm{min}^{-1}\end{array}$ & $\mathbf{R}_{1}^{2}$ & $\begin{array}{c}\mathbf{k}_{2} \\
/ \mathbf{g ~ m g}^{-} \\
{ }^{1} \mathrm{~min}^{-1}\end{array}$ & $\mathbf{R}_{2}{ }^{2}$ \\
\hline \multirow{4}{*}{ RRR } & 1.0 & 0.104 & 0.603 & 0.474 & 0.999 \\
\hline & 5.0 & 0.048 & 0.598 & 0.160 & 0.914 \\
\hline & 8.0 & 0.028 & 0.565 & 0.060 & 0.976 \\
\hline & 10.0 & 0.021 & 0.901 & 0.010 & 0.977 \\
\hline \multirow{2}{*}{ RBB } & 1.0 & 0.030 & 0.900 & 1.126 & 0.997 \\
\hline & 5.0 & 0.076 & 0.496 & 0.053 & 0.967 \\
\hline
\end{tabular}
RBB on $\mathrm{ZnO}$.

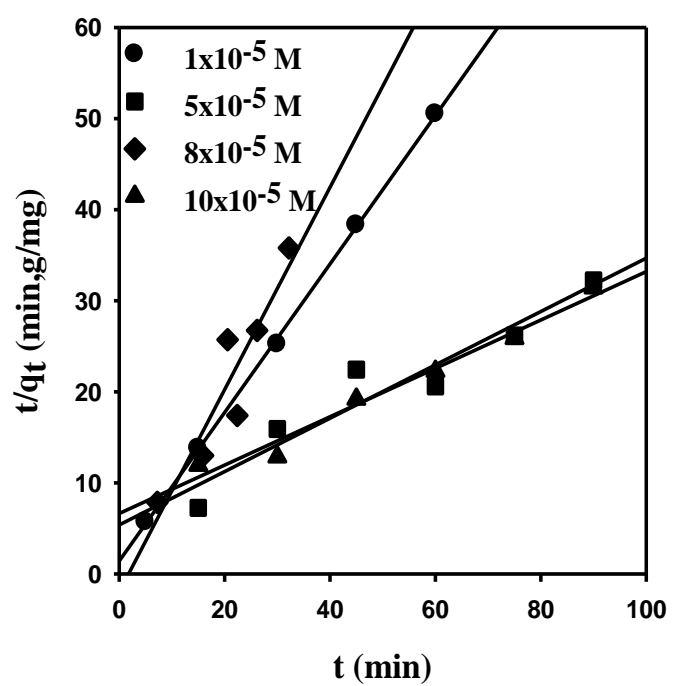

Fig. 4. (b) Pseudo second-order kinetic model for adsorption of $\mathrm{RRR}$ on $0.2 \mathrm{~g} / 30 \mathrm{~mL} \mathrm{ZnO}$ at $\mathrm{pH} 5.83$.

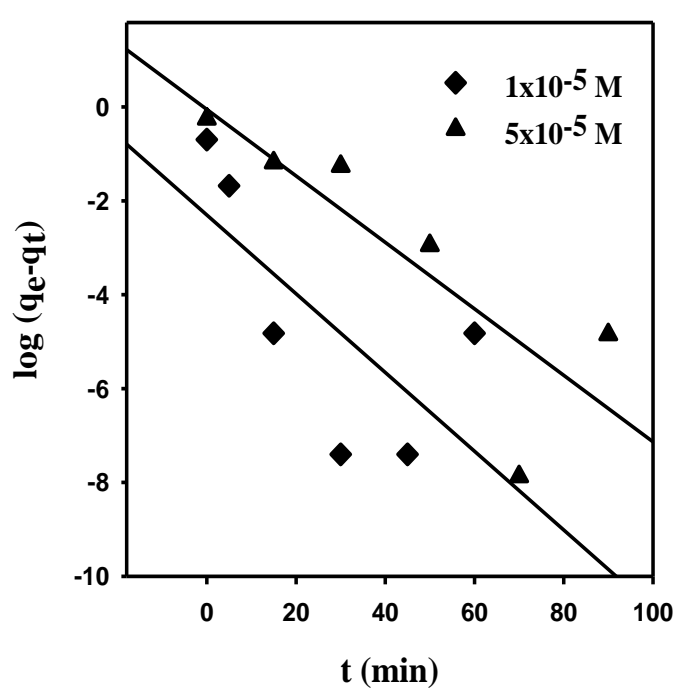

Fig. 5. (a) Pseudo first-order kinetic model for adsorption of RBB on $0.4 \mathrm{~g} / 30 \mathrm{~mL} \mathrm{ZnO}$ at $\mathrm{pH} 5.83$. 


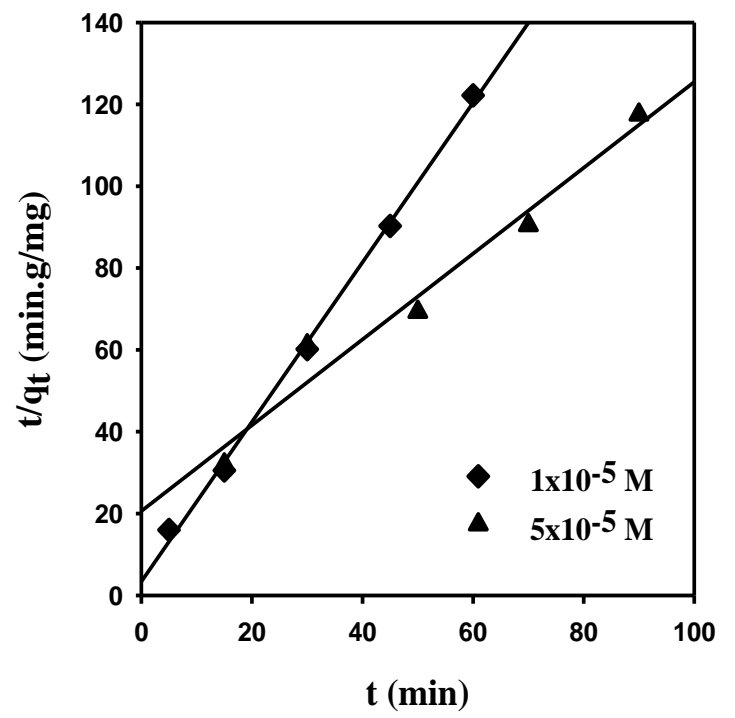

Fig. 5. (b). Pseudo second-order kinetic model for adsorption of $\mathrm{RBB}$ on $0.4 \mathrm{~g} / 30 \mathrm{~mL} \mathrm{ZnO}$ at $\mathrm{pH} 5.83$.

\section{Adsorption Isotherm}

In designing of an adsorption system, the adsorption isotherms are of fundamental importance. In the present work, adsorption of $10 \times 10^{-5} \mathrm{~mol} \mathrm{~L}^{-1}$ of RRR on zinc oxides was studied at three different temperatures and that of $5 \times 10^{-}$ ${ }^{5}$ mol L ${ }^{-1}$ of RBB was studied at two temperatures. Amount of dye absorbed decreases with the increase of temperature (Fig. 6 and Fig. 7) which suggest that both RRR and RBB undergo physical adsorption at the surface of $\mathrm{ZnO}$. Maximum adsorption capacity of RRR was $3.43 \mathrm{mg} / \mathrm{g}$ at $20^{\circ} \mathrm{C}$ and that of RBB was $0.77 \mathrm{mg} / \mathrm{g}$ at $30^{\circ} \mathrm{C}$.

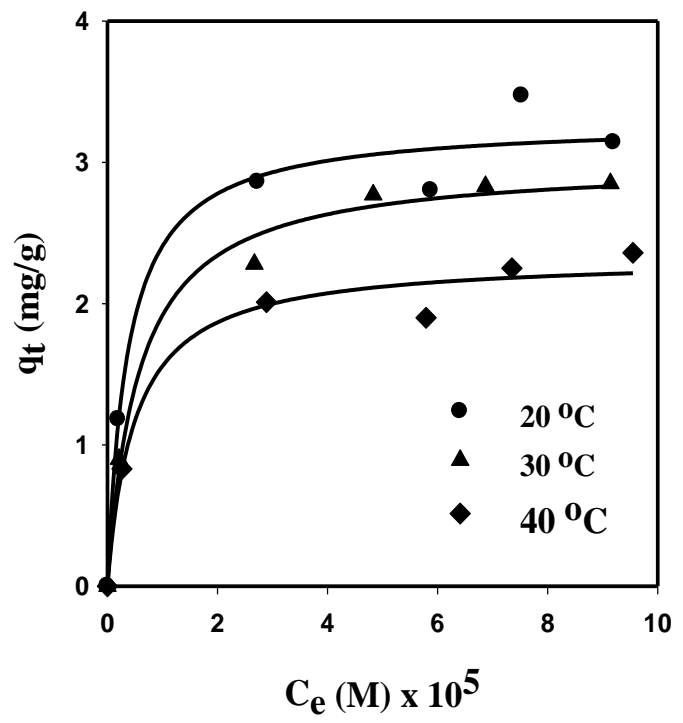

Fig. 6. Adsorption isotherms of RRR on $0.2 \mathrm{~g} / 30 \mathrm{~mL} \mathrm{ZnO}$ at three different temperatures.

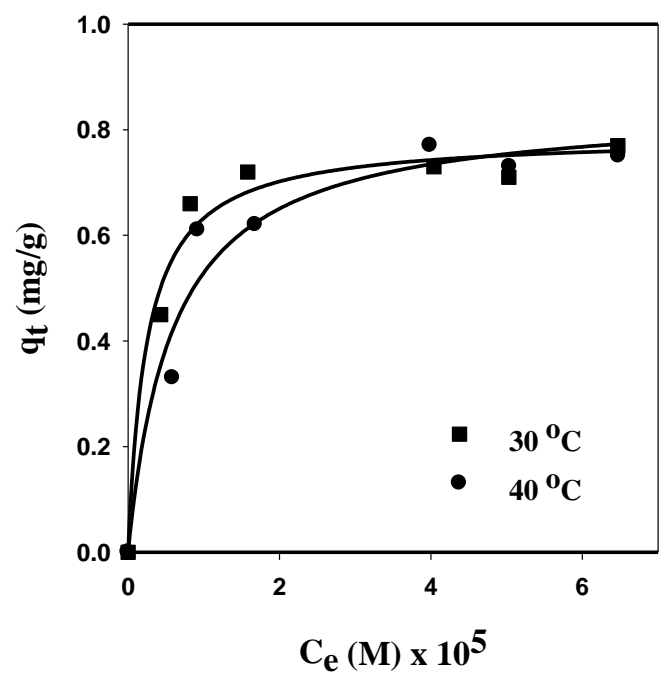

Fig. 7. Adsorption isotherms of $\mathrm{RBB}$ on $0.4 \mathrm{~g} / 30 \mathrm{~mL} \mathrm{ZnO}$ at two different temperatures.

The experimental equilibrium adsorption data were analyzed using the Freundlich ${ }^{31}$ and the Langmuir ${ }^{34}$ isotherm models. The linear form of these two isotherms are expressed by the following equations.

\section{Freundlich isotherm:}

$$
\log q_{t}=\log K_{F}+\frac{1}{n} \log C_{e}
$$

\section{Langmuir isotherm:}

$$
\frac{1}{\mathrm{q}_{\mathrm{t}}}=\frac{1}{\mathrm{q}_{\mathrm{e}}}+\frac{1}{\mathrm{~K}_{\mathrm{L}} \mathrm{q}_{\mathrm{e}}} \frac{1}{\mathrm{C}_{\mathrm{e}}}
$$

Where, $\mathrm{K}_{\mathrm{F}}$ parameter is relative to the adsorption capacity and $\mathrm{n}$ is a measure of adsorption intensity. The Langmuir constant, $\mathrm{K}_{\mathrm{L}}$ is relative to energy ofadsorption and $\mathrm{q}_{\mathrm{e}}$ is the maximum value of adsorption capacity. The values of $\mathrm{K}_{\mathrm{F}}$, $\mathrm{n}, \mathrm{K}_{\mathrm{L}}, \mathrm{q}_{\mathrm{e}}$ are calculated and recorded in Table. 2 along with the values of regression coefficients for Langmuir isotherm $\left(\mathrm{R}_{\mathrm{L}}^{2}\right)$ and Freundlich isotherm $\left(\mathrm{R}_{\mathrm{F}}^{2}\right)$.

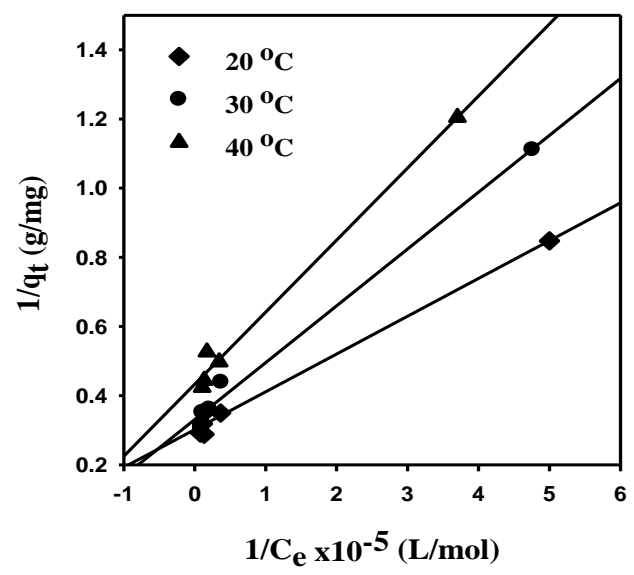

Fig. 8. (a) Langmuir isotherms for adsorption of RRR on $\mathrm{ZnO}$ at different temperatures. 


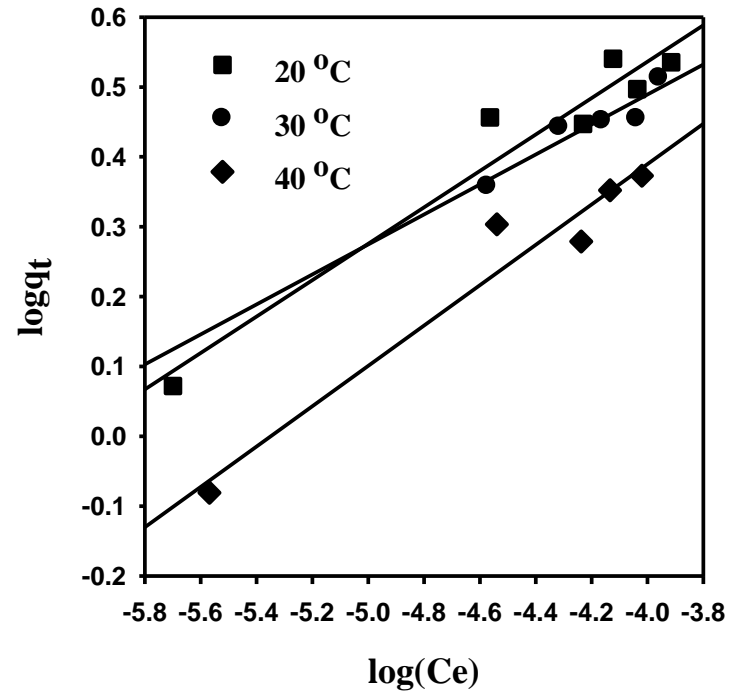

Fig. 8. (b) Freundlich isotherms for adsorption of $\mathrm{RRR}$ on $\mathrm{ZnO}$ at different temperatures.

Table. 2. Characteristic parameters of adsorption process of RRR and RBB on ZnO.

\begin{tabular}{|c|c|c|c|c|c|c|c|}
\hline \multirow{2}{*}{ Dye } & \multirow{2}{*}{$\begin{array}{c}\text { Tempe } \\
\text { rature } \\
/{ }^{\circ} \mathrm{C}\end{array}$} & \multicolumn{3}{|c|}{ Freundlich isotherm } & \multicolumn{3}{|c|}{ Langmuir isotherm } \\
\hline & & $\overline{\mathbf{K}_{\mathbf{F}}}$ & $\bar{n}$ & $\overline{\mathbf{R}_{\mathrm{F}}^{2}}$ & $\begin{array}{c}\mathbf{q}_{\mathrm{e}} / \mathbf{m g} \\
\mathrm{g}^{-1}\end{array}$ & $\begin{array}{l}\mathrm{K}_{\mathrm{L}} \mathbf{x 1} \\
\mathbf{0}^{-5} / \mathrm{L} \\
\mathrm{mol}^{-1} \\
\end{array}$ & $\overline{\mathbf{R}_{\mathrm{L}}^{2}}$ \\
\hline \multirow{3}{*}{ RRR } & 20 & 37.84 & 3.846 & 0.945 & 3.311 & 2.77 & 0.989 \\
\hline & 30 & 61.09 & 3.135 & 0.979 & 3.021 & 2.02 & 0.992 \\
\hline & 40 & 35.08 & 3.472 & 0.949 & 2.039 & 2.08 & 0.989 \\
\hline \multirow[t]{2}{*}{ RBB } & 30 & 3.33 & 6.711 & 0.685 & 0.814 & 3.21 & 0.893 \\
\hline & 40 & 11.72 & 3.636 & 0.714 & 0.941 & 1.08 & 0.834 \\
\hline
\end{tabular}

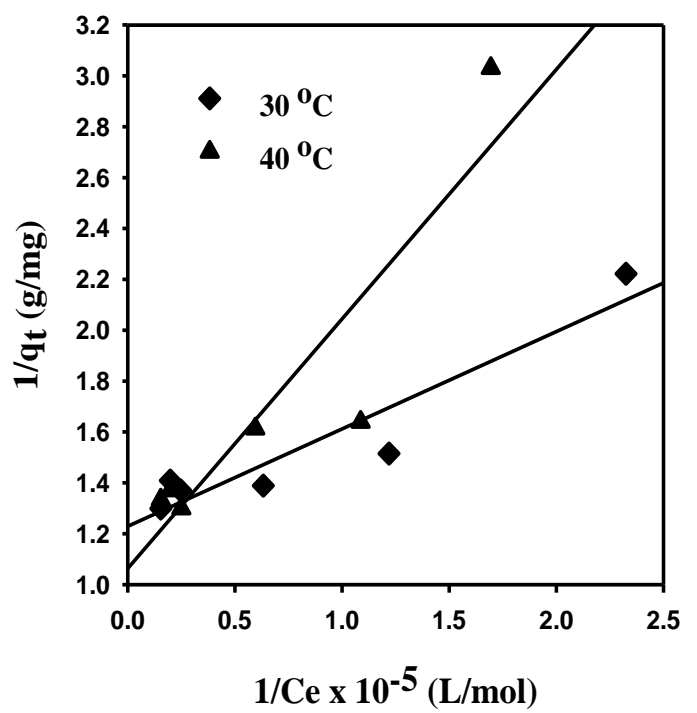

Fig. 9. (a) Langmuir isotherms for adsorption of $\mathrm{RBB}$ on $\mathrm{ZnO}$ at different temperatures.

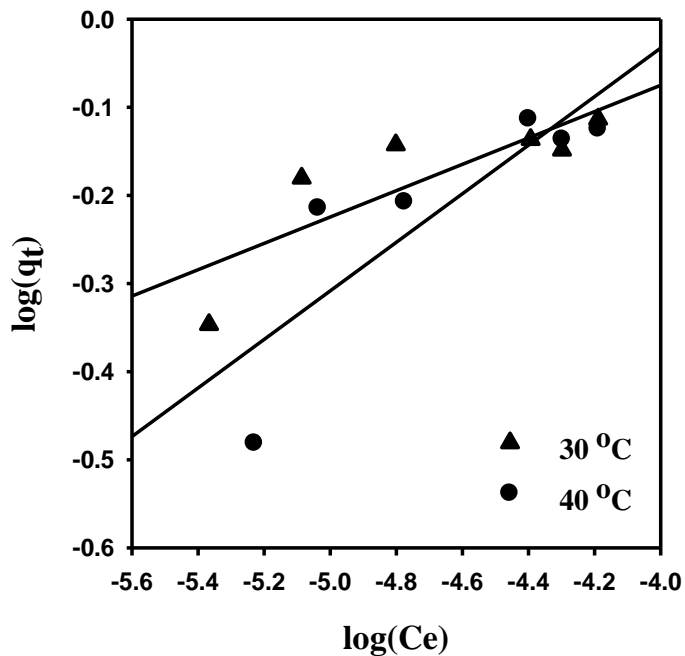

Fig. 9. (b) Freundlich isotherms for adsorption of $\mathrm{RBB}$ on $\mathrm{ZnO}$ at different temperatures.

The values of correlation coefficients $\left(\mathrm{R}^{2}\right)$ for the two models (Table. 2) suggest that the experimental data for both RRR and RBB were more suitable to the Langmuir model than to the Freundlich model. K. Ada et al also found that Langmuir model as a better fit to the adsorption of remazol brilliant blue $\mathrm{R}^{29}$.

Proposed model for adsorption of RRR and RBB on ZnO.

Adsorption of $\mathrm{RRR}$ on $\mathrm{ZnO}$ is approximately three times higher than that of RBB.At $30{ }^{\circ} \mathrm{C}$ temperature, $3.26 \mathrm{mg}$ RRR was adsorbed per gram of $\mathrm{ZnO}$ while amount adsorbed of RBB was $0.77 \mathrm{mg} / \mathrm{g}$ (Fig. 10). Again at $40{ }^{\circ} \mathrm{C}$, amount adsorbed of RRR was $2.36 \mathrm{mg} / \mathrm{g}$ while that of RBB was $0.75 \mathrm{mg} / \mathrm{g}$ (Fig. 11).

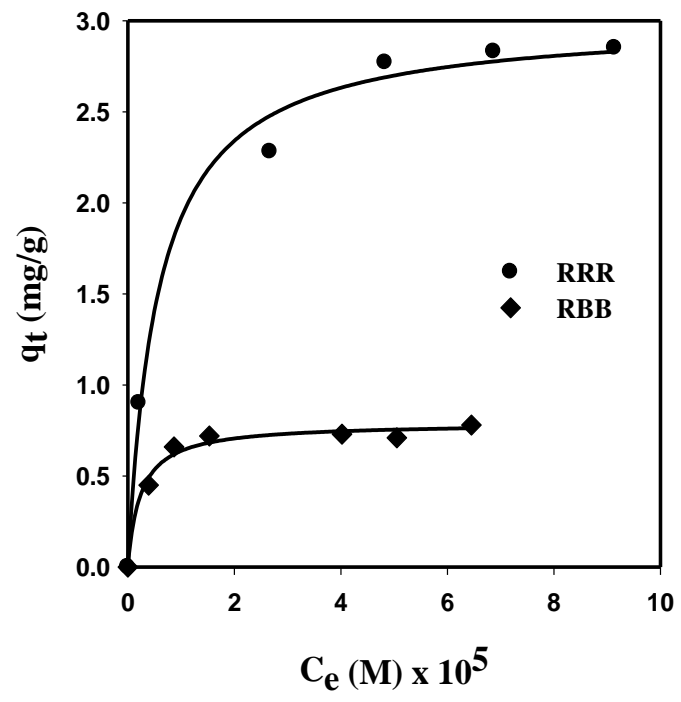

Fig. 10. Adsorption isotherm of RRR and RBB at $30^{\circ} \mathrm{C}$. 


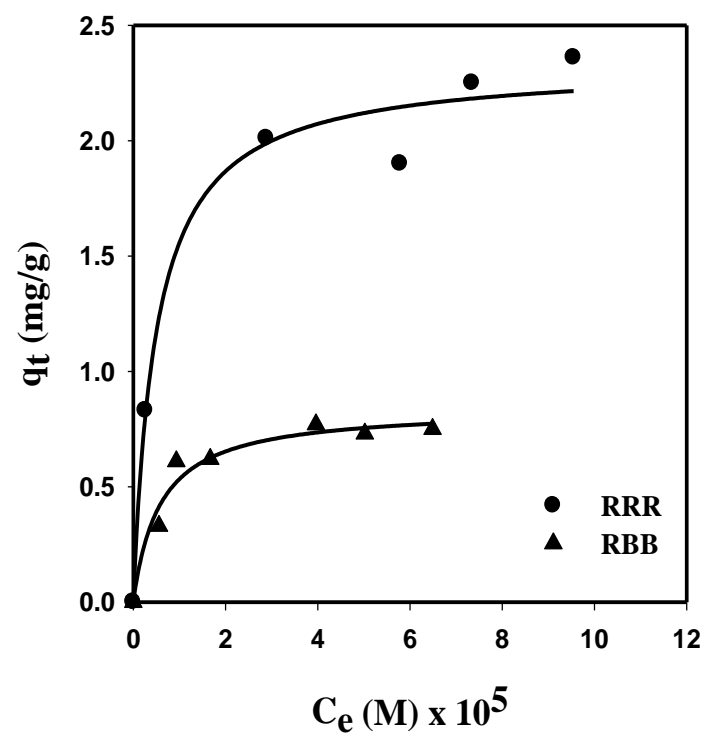

Fig. 11. Adsorption isotherm of RRR and $R B B$ at $40^{\circ} \mathrm{C}$.

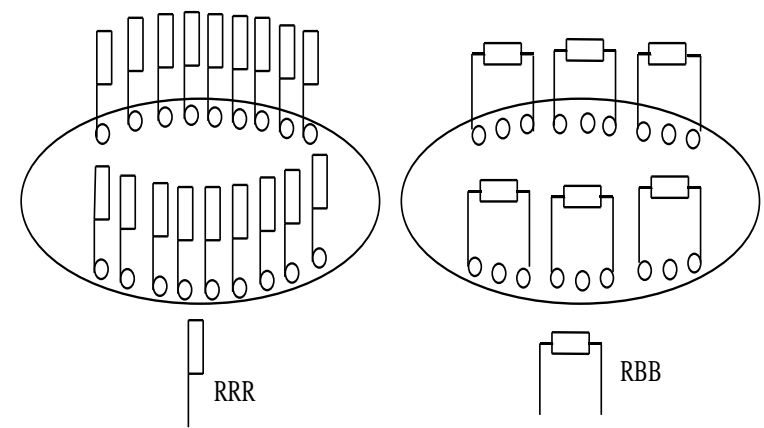

Fig. 12. Schematic representation of the adsorption of RRR and $\mathrm{RBB}$ on the active sites of $\mathrm{ZnO}$ surface.

From the molecular structures (Fig.1a and Fig.1b), we see that RRR has one tail $\left(\mathrm{C}_{6} \mathrm{H}_{5} \mathrm{CH}_{2} \mathrm{CH}_{2} \mathrm{OSO}_{3}-\right)$ whereas RBB has two tails $\left(\mathrm{C}_{6} \mathrm{H}_{5} \mathrm{CH}_{2} \mathrm{CH}_{2} \mathrm{OSO}_{3}-\right)$. It is likely that these tails of dye molecules are adsorbed on the active sites of the adsorbent during adsorption. RBB uses its two tails to attach with two active sites of $\mathrm{ZnO}$ surface, i.e. it adsorbs horizontally. However because of length of the main skeleton, it left one active site as blank (Fig. 12). Thus it is expected that three active sites are used to take up one RBB molecules. On the other hand, RRR uses its one tail to attach with only one active site of $\mathrm{ZnO}$ surface and adsorbs vertically. Every active sites on the $\mathrm{ZnO}$ surface can take up one RRR molecule. Hence, for a given number of active sites on $\mathrm{ZnO}$ surface, RRR molecules shows three times higher adsorption than the RBB molecules.

\section{Conclusion}

The adsorption behavior of $\mathrm{RRR}$ and $\mathrm{RBB}$ on the $\mathrm{ZnO}$ powders in aqueous solution was investigated. Two different kinetic models were used to interpret the results obtained from different concentrations range between $1.0 \times 10^{-5} \mathrm{~mol} \mathrm{~L}^{-1}$ and $10.0 \times 10^{-5} \mathrm{~mol} \mathrm{~L}^{-1}$ for RRR and $1.0 \times 10^{-}$ ${ }^{5} \mathrm{~mol} \mathrm{~L}{ }^{-1}$ to $5 \times 10^{-5} \mathrm{~mol} \mathrm{~L}^{-1}$ for RBB. With the increase of initial concentration, adsortion capacity of the dyes increses. It was found that the adsorption of both RRR and RBB follow pseudo second-order kinetic model. Adsorption of RRR and $\mathrm{RBB}$ on $\mathrm{ZnO}$ was carried out at different temperatures between $20{ }^{\circ} \mathrm{C}$ and $40{ }^{\circ} \mathrm{C}$. Langmuir isotherm model provides better fit compared to the Freundlich isotherm. The amount of dye adsorbed on $\mathrm{ZnO}$ decreases with increasing temperature. This results indicate that the interactions between adsorbate and adsorbent were physical in nature. Maximum RRR uptake was found to be $3.43 \mathrm{mg} / \mathrm{g}$ at $20{ }^{\circ} \mathrm{C}$ for $10.0 \times 10^{-5} \mathrm{~mol} \mathrm{~L}{ }^{-1} \mathrm{RRR}$ solution and maximum RBB uptake $(0.77 \mathrm{mg} / \mathrm{g})$ was observed at $30{ }^{\circ} \mathrm{C}$ for $5.0 \times 10^{-5} \mathrm{~mol} \mathrm{~L}^{-1} \mathrm{RBB}$ solution. Adsorption capacity of RRR was almost three times higher than that of RBB on $\mathrm{ZnO}$ powders due to structural differences. The results suggest that $\mathrm{ZnO}$ can be used as an effective adsorbent material for the removal of RRR and RBB from wastewater.

\section{References}

1. Sadettin, S. and G. Dönmez, 2006. Bioaccumulation of reactive dyes by thermophilic cyanobacteria. Process Biochem, 41, 836-841.

2. Fu, Y. and T. Viraraghavan, 2001. Fungal decolourization of wastewaters: a review. Bioresour. Technol. 79, 251-262.

3. Aksakal, O. and H. Ucun, 2010. Equilibrium, kinetic and thermodynamic studies of the biosorption of textile dye (Reactive Red 95) onto Pinus sylvetris L. J. Haz. Mater. 181, 666-672.

4. Clarke, E. A. and R. Anliker. Organic dye and pigments Handbook of Environmental Chemistry,Anthropogenic Compounds, Part A, 3, Springer, New York, 1980.

5. Dizge, N., C. Aydiner, E. Demirbus, M. Kobya and S. Kara, 2008. Adsorption of reactive dyes from aqueous solution by fly ash: Kinetic and equilibrium studies. J. Haz. Mater. 150, 737-746.

6. Moussavi, G. and M. Mahmoudi, 2009. Removal of azo and anthraquinone reactive dyes from industrial wastewaters using MgO nanoparticles. J. Haz. Mater. 168, 806-812.

7. Mahony, T.O., E. Guibal and J.M.Tobin, 2002. Reactive dye biosorption by Rhizopus arrhizus biomass. Enzyme MicrobialTechnol.31, 456-463.

8. Sun, J. H., S. P. Sun, G. L. Wang and L. P. Qiao, 2007. Degradation of azo dye Amido black 10B in aqueous solutions by Fenton oxidation process. DyesPigments. 74, 647-652.

9. Ozer, A., G. Akkaya and M. Turabik, 2005. Biosorption of acid red 274 (AR 274) on Enteromorpha prolifera in a batch system. J. Haz. Mater.B. 126, 119-127.

10. Lin, S. H. and C. M. Lin, 1993. Treatment of textile waste effluents by ozonation and chemical coagulation. Water Res. 27, 1743-1748.

11. Ganesh, R., C. D. Boardman and D. Michelsen, 1994. Fate of azo dyes in sludges.Water Res. 28, 1367-1376.

12. McKay, G., 1984. Analytical solution using a pore diffusion model for a pseudo irreversible isotherm for the adsorption of basic dye on silica. AIChE J. 30, 692-697. 
13. Annadurai, G., L. Y. Ling and J. F. Lee, 2008. Adsorption of reactive dye from an aqueous solution by chitosan: isotherm, kinetic and thermodynamic analysis. J. Haz. Mater.152, 337346.

14. Slokar, Y. M. and A. M. Le Marechal, 1997. Methods of decoloration of textile wastewaters. Dyes Pig.37, 335-356.

15. O’Neill, C., F. R. Hawkes, D. L. Hawkes, N. Lourenco, H. M. Pinheiro and W. Delee, 1999. Colour in textile effluents - sources, measurement, discharge consents and simulation: a review.J. Chem Technol. Biotechnol. 74, 10091018.

16. Juang, R. S., R. L. Tseng, F. C. Wu and S. H. Lee, 1997. Adsorption behavior of reactive dyes from aqueous solutions on chitosan. J. Chem. Technol. Biotechnol. 70, 391-399.

17. McKay, G., H. S. Blair and J. R. Gardner, 1983. Rate studies for the adsorption of dyestuffs on chitin. J. Colloid Interface Sci. 95, 108-119.

18. McKay, G., 1983.The adsorption of dyestuffs from aqueous solution using activated carbon: analytical solution for batch adsorption based on external mass transfer and pore diffusion. Chem. Eng. J. 27, 187-196.

19. Rao, K. C. L. N. and K. K. Ashutosh, 1994. Color removal from a dyestuff industry effluent using activated carbon. Indian J. Chem. Tech. 1, 13-19.

20. McKay, G., S. J. Allen, I. F. McConvey and M. S. Otterburn, 1981. Transport processes in the sorption of colored ions by peat particles. J. Colloid Interface Sci. 80, 323-339.

21. Ramakrishna, K. R. and T. Viraraghavan, 1997. Dye removal using low cost adsorbents. Water Sci. Tech. 36, 189-196.

22. El-Geundi, M. S., 1991. Color removal from textile effluents by adsorption techniques. Water Res. 25, 271-273.

23. Lee, C. K., K. S. Low and P. Y. Gan, 1999. Removal of some organic dyes by acid-treated spent bleaching earth. Process Biochem. 34, 451-465.
24. Low, K. S. and C. K. Lee, 1997. Quaternized rice husk as sorbent for reactive dyes. Bioresource Tech. 61, 121-125.

25. Hu, T. L., 1996. Removal of reactive dyes from aqueous solution by different bacterial genera. Water Sci. Tech. 34, 89-95.

26. Aksu, Z. and S. Tezer, 2000. Equilibrium and kinetic modelling of biosorption of remazol black B by rhizopus arrhizus in a batch system: effect of temperature. Process Biochem. 36, 431-439.

27. Aksu, Z., 2001. Biosorption of reactive dyes by dried activated sludge: equilibrium and kinetic modeling. Biochem. Eng. J. 7, 79-84.

28. Chiou M. S. and H. Y. Li, 2002. Equilibrium and kinetic modeling of adsorption of reactive dyes on cross linked chitosan beads. J. Haz. Mater. B. 93, 233-248.

29. Ada, K., A. Ergene, S. Tan and E. Yalcin, 2009. Adsorption of Remazol Brilliant Blue $\mathrm{R}$ using $\mathrm{ZnO}$ fine powder: Equilibrium, kinetic and thermodynamic modeling studies. $J$. Haz. Mater.165, 637-644.

30. Haimour, N., R. El-Bishtawi and A. Ail-Wahbi, 2005. Equilibrium adsorption of hydrogen sulfide on $\mathrm{CuO}$ and ZnO. Desilination.181, 145-152.

31. Namasivayam, C. and N. Kanchana, 1992. Waste Banana Pith as Adsorbent for Colour Removal from Wastewaters. Chemosphere. 25, 1691-1696.

32. Wong, Y. C., Y. S. Szeto, W. H. Cheung and G. Mckay, 2004.Pseudo-first-order kinetic studies of the sorption of acid dyes onto chitosan. J. Appl. Polum. Sci. 92, 1633-1645.

33. Ho, Y. S. and G. Mckay, 1998. A two- stage batch sorption optimized design for dye removal to minimize contact time. Trans. IchemE., 76B, 313-318.

34. McKay, G., H. S. Blair and A Findon, 1989. Equilibrium Studies for the Sorption of Metal-Ions onto Chitosan. Indian J. Chem.A.28, 356-360. 
